Article

\title{
Evolution of Short Food Supply Chain Innovation Niches and Its Anchoring to the Socio-Technical Regime: The Case of Direct Selling through Collective Action in North-West Portugal
}

\author{
Fabíola Sostmeyer Polita and Lívia Madureira * \\ Centre for Transdisciplinary Development Studies (CETRAD), Universidade de Trás-os-Montes e Alto \\ Douro (UTAD), Quinta de Prados, 5000-801 Vila Real, Portugal; al67677@utad.eu \\ * Correspondence: lmadurei@utad.pt
}

Citation: Polita, F.S.; Madureira, L. Evolution of Short Food Supply Chain Innovation Niches and Its Anchoring to the Socio-Technical Regime: The Case of Direct Selling through Collective Action in North-West Portugal. Sustainability 2021, 13, 13598. https://doi.org/ $10.3390 /$ su132413598

Academic Editors: Riccardo Testa, Giuseppina Migliore, Giorgio Schifani and József Tóth

Received: 1 November 2021 Accepted: 3 December 2021 Published: 9 December 2021

Publisher's Note: MDPI stays neutral with regard to jurisdictional claims in published maps and institutional affiliations.

Copyright: (c) 2021 by the authors. Licensee MDPI, Basel, Switzerland. This article is an open access article distributed under the terms and conditions of the Creative Commons Attribution (CC BY) license (https:/ / creativecommons.org/licenses/by/ $4.0 /)$.
Abstract: This paper employs MLP (Multi Level Perspective) applied to a study on the transition to SFSC (short food supply chain) innovation taking place in North-West Portugal. MLP allows capturing transition phenomena and analysing them from a perspective that posits intervening factors and events on a three-level scale. Emphasis is laid on the institutional actors and factors that influence these processes, namely the Three Interrelated Analytic Dimensions and Types of Anchoring. Methodologically, personal interviews were conducted with 34 farmers who either are carrying out SFSC initiatives, or have dropped out, or even have never considered participating in them. A process of anchoring the innovation to the local socio-technical regime has been identified, characterised by a low buy-in from institutions and stakeholders. The anchoring that has been found has the peculiarity of occurring only in some points of the intersection between niche and regime, in a process in which it survives bordering this threshold, thanks to the mobilisation of multiple innovations. This type of anchoring, not yet described in the literature, draws attention to a possible pathway that innovations can follow, and brings implications for projects and for policy proposals to support the agroecological transition.

Keywords: transitions; multi-level perspective; short food supply chains; anchoring

\section{Introduction}

Transitions motivated by sustainability that several socio-technical systems are currently undergoing explain the growing interest and developments around Transition Theory. The study of such transition processes has focused on understanding what triggers them and how they are developed, namely to ascertain how they can be accelerated by public policies. Transition Theory originated in studies on the sociology of technology like Rip and Kemp's [1], illustrating the role played by technology in society and vice-versa. In 2002, the theory acquired a schematic perspective and a graphic representation, following Geels' improvements, which resulted in the Multi-Level Perspective (MLP) [2,3]. According to Geels, the MLP results from the integration of different contributions and establishes a novel theoretical framework that combines "analytical and heuristic concepts to understand the complex dynamics of sociotechnical change" [4] (pp. 1259). Geels [4] proposes a dynamic combination of events structured in three levels leading to the heuristics that can explain the evolution of technological transitions triggered by introducing innovation in sociotechnical regimes.

In the present study, MLP will be used to look into a non-technological innovation, encompassing changes in organisational, marketing and value-chain aspects, configuring the creation of a Short Food Supply Chain (SFSC) [5] in order to understand how it unfolds as an agri-food system transition in the northwest of Portugal. This Portuguese region is particularly marked by its vocation for horticultural and fruit production activities usually developed in small family farm holdings. Especially after 2008, this region has taken on an 
innovation within the SFSC, in which groups of small family farmers organised themselves to directly supply final consumers with products from their farms [6,7]. This direct selling innovation, which incentivises farmers to cooperate with each other, was introduced by Local Development Associations (LDAs) aiming at increasing small family farmer income while helping them market their products. It is, then, an organisational and collaborative innovation aiming at changing the way farmers do business and one which can, therefore, be looked at as a way of innovating both marketing and the value chain.

Under the MLP, one can assume that in the area under study, direct selling of fruit and vegetable baskets is an innovation, which, at the time of the empirical research, in 2018, represented a link to the local socio-technical regime. In other words, it corresponded to an initiating transition conventionally referred to as anchoring. In this sense, the present study is in line with Smith's [8] and Elzen's et al. [9] view that these initiating transitions must be looked into and systematised using several case studies in order to identify and clarify those processes which have not yet been dealt with in specialised literature [9], as well as to identify whether there are patterns that represent them [10]. The present research paper introduces an original contribution to develop the understanding of the anchoring processes in the MLP framework. It presents a case of marginal anchoring, where only a few niche actors connected to the mainstream regime, where farmer bulk sell prevails, by combining the direct selling of fruit and vegetable baskets with the development of an array of other complementary innovations. Thus, it was possible to continue innovating, albeit in an incremental mode.

From a theoretical viewpoint, MLP and its analytical levels of the socio-technical system will be combined with other aspects on which transitions are also based, such as infrastructural and institutional aspects and the collaboration between stakeholders and organisations [11]. To that effect, the Three Interrelated Analytic Dimensions proposed by Geels in 2004 [12] will be used; emphasis is put on individual and collective action-related aspects (human actors, organisations, and social groups) as well as on regulatory and institutional aspects (rules and institutions) and factors that need to be taken care of so that innovation may be structured and pave the way to transition. Elzen et al. [9] also drew attention to the fact that transitions imply having the necessary institutional conditions and a suitable actor-network to unfold positively, which one can refer to as Types of Anchoring and which will also be looked into in greater detail. Although Three Interrelated Analytic Dimensions have an analytical character, as its name suggests, here they will also be applied from a structural perspective, assuming that for an innovation to succeed, both human and organizational aspects and regulatory and institutional ones must affect the elements of the socio-technical system.

In general, the present paper is a contribution to the development of MLP, in need of further research as regards the agri-food system [13]. Moreover, studies on initiating transitions may help enrich MLP and its explanatory power. By depicting a specific transition event - in which innovation anchors to the socio-technical regime-the present study helps create a scientific framework, albeit still in its early stages, to explain the peculiarities of the anchoring phenomenon [8,9]. The concept of anchoring is operationalised by using MLP and by observing and analysing the trajectories of innovation niches, understood by gathering the path narratives of the interviewed farmers. Due to its particular nature, this paper also pioneers the describing of an innovation event capable of surviving in the threshold between niche and regime by the ability of farmers leading the innovation niches to develop complementary innovations that strengthen their innovative approach of direct selling despite conventional bulk selling that prevails in the regional agri-food regime.

The methodological sequence combines the analysis of statements gathered from 34 interviews of farmers, including: (a) those who have developed basket direct selling and anchored to the regime (the "adopters"); (b) farmers that introduced the innovation but that abandoned (the "droppers") and returned in most of the cases to their previous status quo; and, (c) farmers that didn't even considered adopting the innovation, despite being aware of it (the "non-adopters"). 
Special attention has been given to the actions of farmers and regulatory and institutional structures dedicated to supporting the consolidation of innovations, aligning these farmer experiences and reports with a set of conditions that go beyond innovation itself or the socio-technical system to describe the transition attempt.

The paper is, then, structured as follows, from Section 2.1 presents the theoretical framework related to socio-technical transitions and the principle of linking niche innovations to the socio-technical regime described in the literature as anchoring; and Section 2.2 presents the theoretical approach concerning the innovation of basket direct selling as a SFSC. Section 3 lists the resources and methods used and presents the region under survey characterising the innovation of basket direct selling. Section 4 provides the results of the study. Section 5 explains the marginal anchoring process, considering the institutional dimensions and the stakeholders involved. Finally, the conclusions of the article are presented.

\section{Theoretical Approach}

\subsection{From Transition Theory to Anchoring}

The word transition comes from Latin and refers to the process of going from one form, state, style, or place to another [14]; due to the notion of crossingthat it entails, the word has been used in studies referring to technical and social change [15]. For analytical purposes, Transition Theory has been operationalised through MLP. MLP is an analysis perspective for transition cases [16] that articulates three conceptual levels known as niche (microlevel), regime (intermediary level), and landscape (macro-level); it is used to explain what causes innovation processes to emerge and how they can reconfigure already stabilised socio-technical regimes [17]. The three levels shape the socio-technical system, and the transition takes place when innovations occur at the niche level and manage to override the regime and reconfigure it. The whole process always takes place under the influence of the socio-technical landscape [18].

In short, the niche, MLP's micro-level [4], represents the locus of radical innovations, or the protected environments in which innovations are endowed with investments, resources, knowledge, and skills to structure themselves [19]; this may entail pilot-projects, market segments, and research and development networks [20]. The niche is also acknowledged as an environment that enables innovations to develop outside the scope of market pressure [10]. The regime is MLP's intermediary-level [4]. It refers to practices, technologies, rules, and institutions already in place in society that guide and legitimise how science and technologies are produced [21]. It also refers to a system of interaction practices and structures that have reached a certain relative stability and status quo within a given sector [22]. The landscape, MLP's macro-level [4], represents the context variables [23]. In a broad sense, it may be described as the exogenous socio-technical scenery composed of the ideologies, macro-economic patterns, cultural and climate changes, and demographic tendencies that influence niches and regimes $[18,24]$.

However, before innovations and regimes are totally superimposed, there is a stage Elzen et al. [9], inspired by Loeber [25] and Smith [8], called anchoring. Anchoring means the set of facts or events that cause innovations to adhere to the regime. Therefore, it depicts a phenomenon that is usually surrounded by uncertainty because innovations leave the protected space of the regime to meet a new dynamics dictated by the latter's peculiar stability. Innovations may be rejected by regime actors and disappear, or, on the contrary, be accepted and cause the regime to change. Smith [8] notes literature treats these links as random and coincidental, stressing that there should be a theory (which he calls the Theory of Linking) to deal with these phenomena, but, so far, none has been suggested. Elzen et al. [9] believe unravelling these anchoring dynamics must be one of the concerns of current research to ascertain whether these events obey patterns and whether or not it is possible to predict their unfolding.

The transition from a socio-technical system is commonly represented schematically through MLP [26,27]. To this graphic representation, the anchoring event was added to 
make explicit the emergence of innovative dynamics, their possible link to the regime, and the changes they may cause under the socio-technical landscape in the space versus MLP levels (Figure 1).

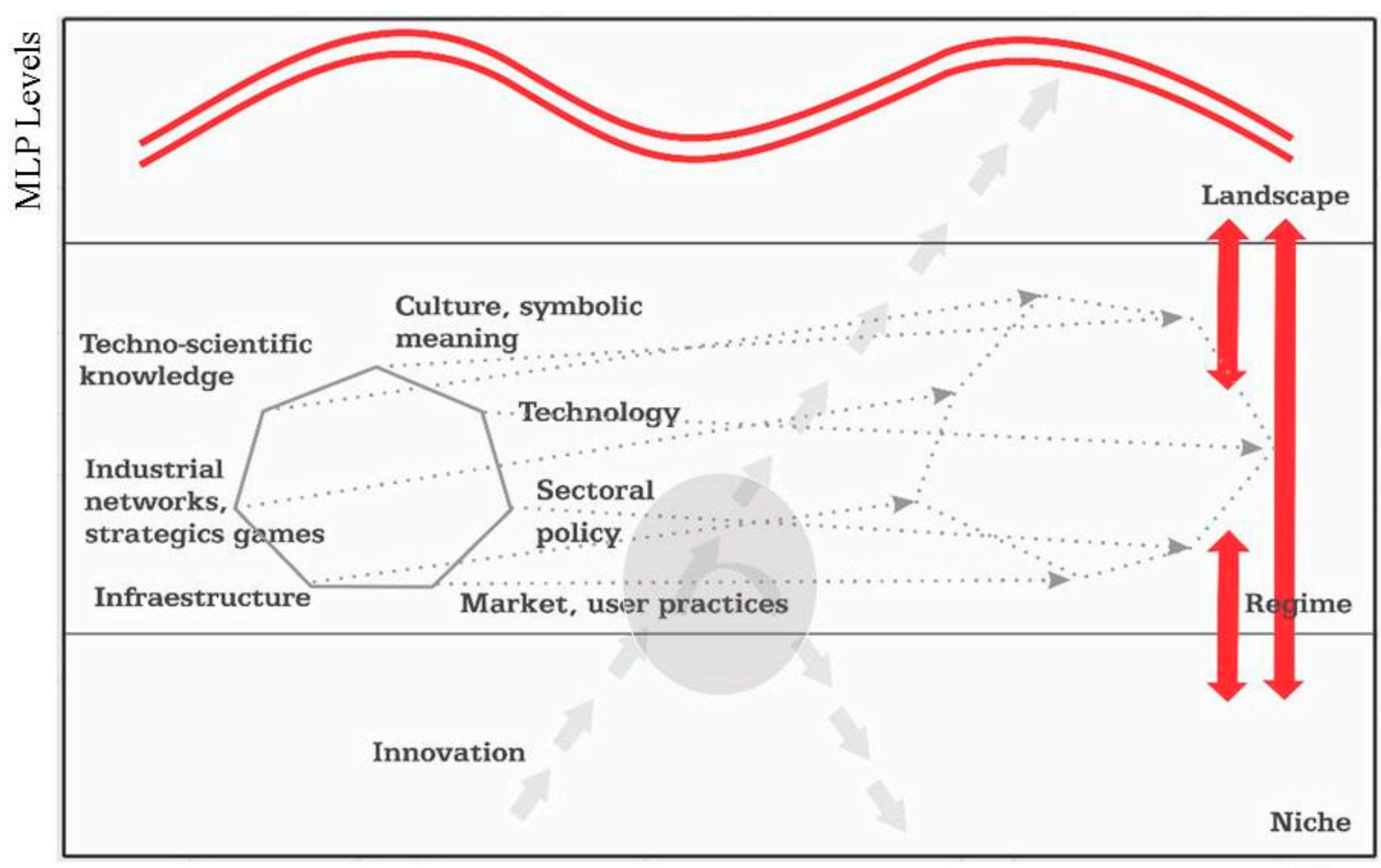

Time

Figure 1. MLP's conceptual and dynamic levels (interpreted according to Geels [4] expressing an anchoring process. (Figure produced by the authors).

The figure shows the niche, regime and socio-technical landscape conceptual levels (a socio-technical system) in a space versus MLP level representation. Innovations (grey arrows) may go on different paths. They may have a regressive trajectory or may progress and enter the regime. In the latter case, they may start changing the regime, here represented by the heptagon the extremities of which are its stable elements. As innovations go on, there may occur a reconfiguration of the regime, the dotted line on the right representing its future composition. The central grey halo is the anchoring event or set of events which mark the beginning of the innovations' link to the regime. At the top level are the context socio-technical variables (the landscape) which both influence and are influenced by the other levels (illustrated by the red arrows on the right).

It is important to note that an anchoring process is not only the linking of niche innovations to the regime. It may also be their linking to several other niches [2]. As it has been suggested by Ingram [28] and Ingram, Maye, and Kirwan [29], anchoring processes regard not only niche agent efforts to anchor to the regime, but also to answer to the actions and pressures of the niche, a process that is reflexive and entails learning processes, actions, and network formation. Table 1 shows a compilation of studies on MLP's conceptual levels applied to certain types of transitions in agriculture. It is worth mentioning these articles do not always explicitly refer to anchoring processes, but their analysis reveals the presence of a dynamic that occurs in the niche-regime interface. In general, the summary of articles includes anchoring issues or the dynamic interactions in the interface, which, so far, have not made their way into specialised literature. 
Table 1. Studies on anchoring or relations between levels in agriculture-related transitions.

\begin{tabular}{|c|c|}
\hline Reference & Contribution to Studies on Anchoring \\
\hline $\begin{array}{l}\text { Elzen, van Mierlo and } \\
\text { Leeuwis (2012) [9] }\end{array}$ & $\begin{array}{l}\text { This study suggests anchoring is an analytical concept to explain the continuous process of } \\
\text { establishing and breaking relations between niches and regimes and among niches. }\end{array}$ \\
\hline $\begin{array}{l}\text { Diaz, Darnhofer, Darrot and } \\
\text { Beuret (2013) [30] }\end{array}$ & $\begin{array}{l}\text { This study emphasises the social role of transitions, highlighting that neither niches nor regimes } \\
\text { are static entities; on the contrary, they act and react with and to each other. It suggests anchoring } \\
\text { is not a sequential process but a continuous and recurrent one. }\end{array}$ \\
\hline $\begin{array}{l}\text { Slingerland and Schut (2014) } \\
\text { [22] }\end{array}$ & $\begin{array}{l}\text { This study shows niche-regime interactions need efficient conditions if they are to } \\
\text { be implemented. }\end{array}$ \\
\hline Ingram (2015) [28] & $\begin{array}{l}\text { This study deals with anchoring as an adaptive process, whereby niches and regimes adapt to } \\
\text { each other as a result of reflexive and learning processes on the part of the actors involved. }\end{array}$ \\
\hline $\begin{array}{l}\text { Ingram, Maye, Kirwan, } \\
\text { and Kubinakova (2015) }\end{array}$ & $\begin{array}{l}\text { This study suggests transition to sustainable agriculture may be looked at as interactive and } \\
\text { adaptive complex changes rather than a regime shift. }\end{array}$ \\
\hline $\begin{array}{l}\text { Sutherland, Peter and Zagata } \\
\qquad \text { (2015) [31] }\end{array}$ & $\begin{array}{l}\text { This study addresses multiple regimes of renewable energy production by the agricultural sector, } \\
\text { suggesting the emergence of a new regime out of the political role of this type of process. }\end{array}$ \\
\hline $\begin{array}{l}\text { Bui, Cardona, Lamine and } \\
\text { Cerf (2016) [10] }\end{array}$ & $\begin{array}{c}\text { This study identifies common anchoring phases or patterns in four studies regarding agency and } \\
\text { governance factors. }\end{array}$ \\
\hline $\begin{array}{l}\text { Vankeerberghen and } \\
\text { (2016) [32] }\end{array}$ & $\begin{array}{l}\text { This study develops the concept of insularisation to characterise the process whereby a niche } \\
\text { develops within a regime and gradually and steadily detaches from it. }\end{array}$ \\
\hline $\begin{array}{l}\text { Belmin, Meynard, Julhia and } \\
\text { Casabianca } \\
\text { (2018) [33] }\end{array}$ & $\begin{array}{l}\text { This study does not explain what an anchoring process is, but it gives an example of a relation } \\
\text { between niche and regime in which innovations are not necessarily aligned with the niche, but } \\
\text { are a subsystem of the regime. This perception even suggests new transition concepts. }\end{array}$ \\
\hline $\begin{array}{l}\text { López-García, Calvet-Mir, Di } \\
\text { Masso, and Espluga (2019) [17] }\end{array}$ & $\begin{array}{l}\text { This study stresses the importance of creating hybrid forums that may become interaction loci } \\
\text { between niche actors and regimes. Through these forums, innovations could overcome the } \\
\text { regime by linking themselves to different types of actors. }\end{array}$ \\
\hline $\begin{array}{l}\text { Schiller, Godek, Klerkx and } \\
\text { Poortvliet (2020) [34] }\end{array}$ & $\begin{array}{l}\text { This study creates a time line to explain the development of a specific niche: the agroecological } \\
\text { niche. The conclusion is that the agroecology did not necessarily create a transition but was } \\
\text { incorporated into the regime. }\end{array}$ \\
\hline
\end{tabular}

In short, the above-mentioned articles suggest anchoring processes both rest on conditions that emerge from the niche-regime relationship, and depend on other factors like the institutional context and the relationship between actors. Consequently, the present analysis will depart from the Types of Anchoring proposed by Elzen et al. [9]. Elzen and his collaborators [9] admit that the linking of innovations to the regime, that is anchoring, must take place in three areas: technological, institutional, and network-related. The present study will disregard technological anchoring since the direct selling of fruit and vegetable baskets is not exactly technological innovation.

The areas or Types of Anchoring are based on Geels' studies [11]. Geels [11] has suggested innovations happen through the articulation of the socio-technical context-the object of analysis of the MLP - with two other dimensions: the rules and institutions, and the human actors, in other words, the organisations and the social groups. Together, these two dimensions are what Geels calls Three Interrelated Analytic Dimensions although the Three Interrelated Analytic Dimensions correspond to the Types of Anchoring suggested by Elzen et al. [9]. If Three Interrelated Analytic Dimensions are essential in an innovation process, it is to be expected that they are also important at the beginning of the transition. Table 2 shows Three Interrelated Analytic Dimensions and the Types of Anchoring composing elements that need to be articulated for a transition to take place. 
Table 2. Elements that compose Types of Anchoring and Three Interrelated Analytic Dimensions.

\begin{tabular}{|c|c|}
\hline \multirow{3}{*}{$\begin{array}{l}\text { Three Interrelated } \\
\text { Analytic Dimensions }\end{array}$} & $\begin{array}{l}\text { 1. Socio-technical systems: involve actor networks gathered around a specific institutional structure to } \\
\text { disseminate a technology; they also include knowledge flows or skills required by the technology [35]. }\end{array}$ \\
\hline & $\begin{array}{l}\text { 2. Rules and institutions: refer to normative, cognitive, and regulatory aspects [36] of how innovations } \\
\text { emerge. }\end{array}$ \\
\hline & $\begin{array}{l}\text { 3. Human actors, organisations, and social groups: may refer to enterprises that create technologies, or } \\
\text { political actors who legislate it, or the users of a novelty [12]. }\end{array}$ \\
\hline \multirow{3}{*}{ Types of Anchoring } & $\begin{array}{l}\text { 1. Technological: concerns technological innovations when actors define the technical features of the } \\
\text { novelty [9]. }\end{array}$ \\
\hline & $\begin{array}{l}\text { 2. Institutional: represents the universe of rules (cognitive, interpretative normative, and economic) } \\
\text { mobilised, adapted, or created to support innovations [9]. }\end{array}$ \\
\hline & $\begin{array}{l}\text { 3. Network-related: means a shift in the relationship between actors (contacts, exchanges, } \\
\text { interdependencies, and coalitions) that change as a novelty develops [9]. }\end{array}$ \\
\hline
\end{tabular}

According to Three Interrelated Analytic Dimensions and Types of Anchoring, both innovation and anchoring must have agency and governance components, organised in innovation design and using networks if they are to take place [37]. They also share the need for an institutional dimension that regulatorily supports them (such as laws, sanctions, protocols, and power and governance systems) [36]. Ergo, Three Interrelated Analytic Dimensions and Types of Anchoring are practically equivalent.

\subsection{Basket in Direct Selling as Short Food Supply Chains (SFSC)}

As regards basket direct selling, we can refer to it as a methodology of organising farmers into small groups to assemble and distribute agricultural product baskets directly to the final consumers (restaurants or individuals). This type of innovation clearly has a collaborative feature since the aim of the methodology is to motivate farmers to work collectively in assembling and distributing baskets directly to consumers, besides managing the project. The basket direct selling were originally proposed within the Equal Community Initiative. In Portugal, this initiative was launched and managed by Local Development Associations (LDAs). It was formally established in 2004 and planned to develop in three stages: identification, development, and dissemination. These stages went on up to 2009 and the initiative was expected to last until 2012 within the LEADER Programme financed by the Portuguese Rural Development Programme (RDP) [38]. The structuring of the initiative implied farmers should assemble baskets of fresh agricultural products and deliver them directly to final consumers. The baskets should include only seasonal products of local varieties produced according to traditional farming methods. Besides making the supply chain shorter, direct selling would establish a deeper link and commitment between farmers and consumers, allowing the former to aggregate value onto their products and increase their income. After enrolling participants and publicising the program through various media, responsibility for its management ceased to be that of the Local Development Association and became that of the farmers [7,39,40].

Basket direct selling characterises a SFSC, which can be described as direct-to-consumer marketing practices in which food product distribution has few or preferably no intermediaries [41]. They became popular worldwide as an opportunity to generate income and help small farmers sell their products, especially those who have difficulties accessing the markets and who otherwise obtain low-profit margins [7,42].

According to specialised literature, it was only in the last two decades that SFSCs began to receive more attention [43]. The available scientific literature currently relates SFSCs to potential gains in sustainability insofar as they would be capable of: promoting reduction of food waste, improving food safety, and increasing farmer profits and product quality [44]. Other gains would be, for instance, establishing a relation between SFSCs and social issues, mentioning the increase of the level of employment, and the building of a sense of belonging to a group or a community [45]. Some studies refer to SFSCs as models 
to broaden sustainability by granting farmers fairer payments. This makes them promoting factors of local development [46]. The use of more sustainable agricultural practices due to the increase of biodiversity and the adoption of more ecological methods is also an advantage of SFSCs. Farmer direct contact with the final consumer helps them comply with the latter's demand for more sustainable products [45,47].

Recent research shows that SFSCs express themselves as heterogeneous phenomena, and that their members perceive them as a form of distribution capable of conferring greater sustainability to the agri-food system, as well as being potentially beneficial to farmers in economic terms. They also identify that farmers tend to participate in several SFSCs at the same time, trying to obtain benefits from several of them, and even that they are able to attribute greater gender equity at work in certain operations [48,49]. Malak-Rawlikowska et al. (2019) [48] even state that when taking into account market evolutions, SFSCs tend to develop to the point of competing with long supply chains, forcing them to offer better conditions for farmers.

SFSCs can be said to have a collaborative dimension, as farmers have to work together in assembling and distributing their agricultural products for direct-to-consumer marketing purposes, and in personally managing their own supplier and customer groups. As Ziegler has pointed out [50], collaborative innovation obeys human dynamics, in the course of how people work, as they exchange content, information, and knowledge with other people from other groups who sometimes share concepts and practices of different-even opposite-areas and disciplines. By implying the integration of people and users, these collaborative practices consolidate in the form of trans- and multidisciplinary exchanges of knowledge, requiring participants to have the skill to learn, integrate and co-create from previously acquired knowledge [51]. Thus, collaborative innovation goes beyond the mere access to information; it is an integral part of the dynamics of new skills building and acquisition [52] and results from mutual learning experiences generating new knowledge and solutions [53].

\section{Materials and Methods}

\subsection{Presentation of the Region under Study and Characterisation of the Novelty}

The study area, Tâmega e Sousa (NUTS III-The Nomenclature of territorial Units for Statistics) is located in northwest Portugal, more specifically between the Sousa River Valley, near Porto, and the region to the east known as Baixo-Tâmega (Figure 2). It was selected because of an innovation dissemination process that had been going on there for some years: the direct selling of farm product baskets. The basket direct selling has been considered an innovation process in keeping with Rogers' studies [54]. The author sees innovation as a concept or idea, as technical information or an actual practice that is perceived by the individual or unit adopting it as something new, stemming from new routines in the ways farmers work introduced through the group dynamics of organising, distributing and attracting clients. Note that small farms prevail in this region, of which $84 \%$ have less than 5 hectares [6].

\subsection{Data Collection}

Data collection took place between April and October 2018 through personal interviews of 34 farmers who either are currently involved in developing the basket direct selling innovation, have given it up, or have never even considered doing it. Interviewees were selected according to the convenience criterion using non-probabilistic sampling techniques resorting to reference chains [55], known as snowball, whereby each interviewed farmer indicated another. The number of interviewees was determined by exhausting the introduction of new information. 


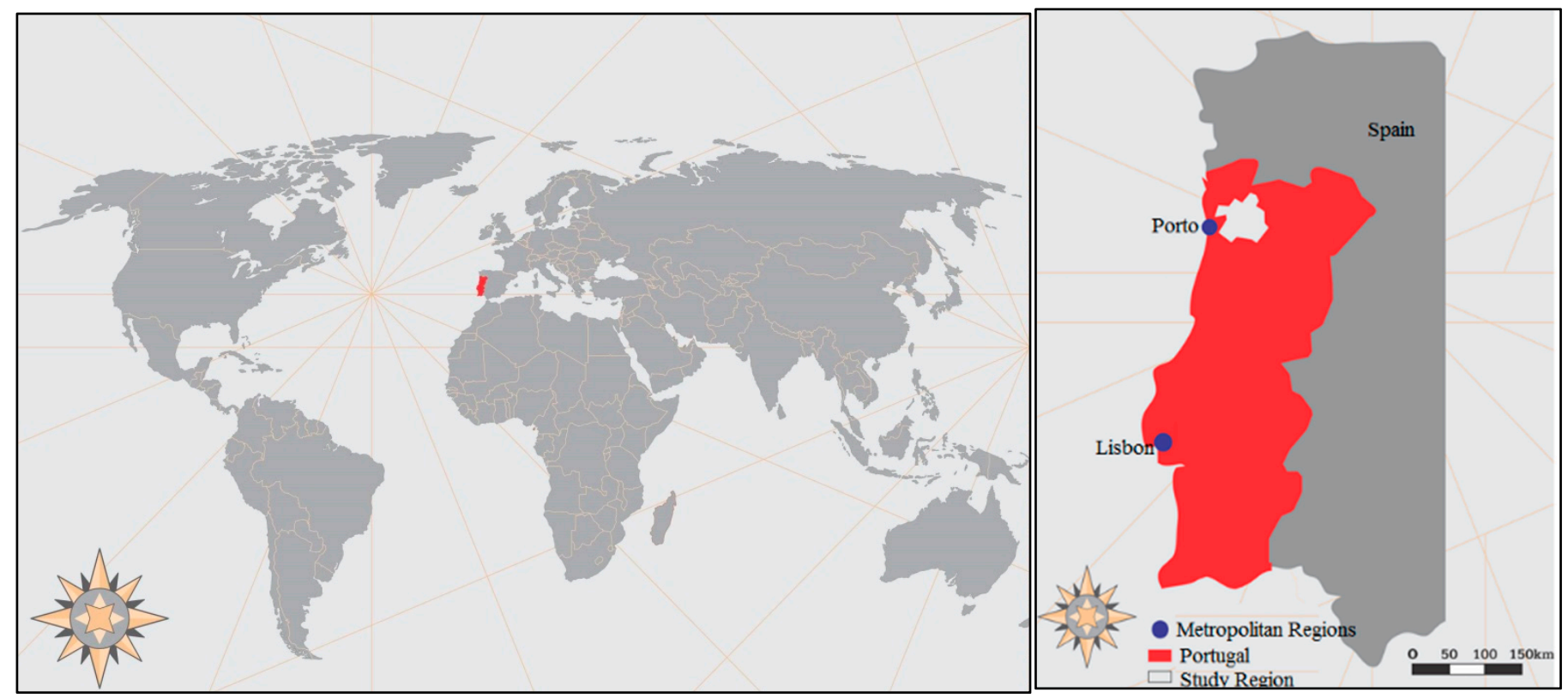

Figure 2. Relative position of the study region, in northwest Portugal, regarding Porto metropolitan area and the capital, Lisbon.

The interview script was developed within the AgriLink Project [56] englobing 53 topics and combining qualitative and quantitative open and closed questions structured to: 1 . characterise the farm; 2 . identify the farmers' sociodemographic profile; 3 . capture information on farmer business model and farm structure; and 4. understanding the interviewee's relationship with innovation. (The AgriLink Project-Agricultural Knowledge: Linking farmers, advisors and researchers to boost innovation, was developed within the Grant Agreement n 727577 of the Horizon 2020 Projects (https:/ / www.agrilink2020.eu/, accessed on 31 January 2021). The empirical research for the present article was conducted within the context of the mentioned project, following its conceptual and empirical methodology to gather qualitative and quantitative data, although only the former was used.) Interviews were conducted with the purpose of capturing farmer narratives regarding the innovation-related practices and concepts they develop. This was done in a perspective of understanding how innovation evolves and the path it takes (farmer narratives on their own innovation path). Note that the content of the interviews was registered on paper and recorded, according to the interviewees' permission. Farmer narratives on describing their innovation paths were transcribed to be analysed through the technique of content analysis [57].

Historical information gathered from scientific papers, documents, and reports has been added to complete the data and to understand the context where the innovation took place. This way, based on researcher observations and comments, an innovation's evolutionary path was built, revealing the changes it caused. In the present analysis, priority was given to relating narratives and the gathered data with innovation pathways proposed by MLP by integrating events with Three Interrelated Analytic Dimensions and Types of Anchoring.

It is emphasised that, as pointed out by Geels [18], there isn't a methodology specifically designed for transition empirical studies using MLP. The author also mentions that it is up to the scientist to delineate the empirical framework and that this should be creative in combining techniques and interpretations to link the facts, from different origins and levels, as well as the analyses.

For clarification purposes, MLP's analysis levels have been delimited. Thus, basket direct selling represents niche innovation, and the regime is the agri-food sector of the NUTS III Tâmega e Sousa, in the northwest of the country (Figure 2). In the present case study, the landscape has a quality that is both supranational and European. 


\section{Results}

\subsection{Implementing Innovation}

Basket direct selling was introduced in Portugal as pilot-projects close to the capital, Lisbon, under the designation "PROVE-Promover e Vender" (Promote and Sell) in the middle of 2006. (In Portuguese, by joining the beginning of the verb "promover", which means promote, and the beginning of "vender", which means sell, one gets the word "prove", which means taste. Naturally, the wordplay is lost in translation.) These projects consisted of structuring farmers in small groups to collectively assemble fruit and vegetable baskets to deliver to urban consumers. Each farmer would supply their production specialties or their seasonal surplus [58]. In 2008, the initiative attracted supporters from other regions of the country as part of the project's expansion strategy. The Local Development Associations became, then, responsible for launching and managing the proposal in its pilot stage. Thus, innovation reached Tâmega e Sousa, a region deemed promising for the project's development because of its proximity to Porto's urban centre and its residents, the potential buyers of the baskets. Over time, innovation incorporated other resources: buyers were able to select from a list of products available those they would be consuming and started ordering through online apps.

In general, basket direct selling gained visibility and supporters among the interviewees between 2012 and 2013; some even mentioned having been practicing some type of direct selling for longer, more precisely since 1980. Farmers reported that, initially, when it was being divulged and implemented, the initiative could count on the support of LDAs and other local actors such as municipalities. Only after 2008, when basket direct selling experienced their greatest expansion and implementation, did farmers begin to diverge regarding how to try to manage this novelty.

\subsection{Distinguishing between Pathways}

Farmer narratives show that their experiences with direct-to-consumer marketing vary widely, breaking down as follows: $35.3 \%$ of respondents chose to give up the basket direct selling innovation, especially between 2012 and 2014; 44.1\% of respondents continue to sell their products directly to consumers, although the groups now have fewer participants (the groups started with 6 to 8 farmers and, at the time of the research, were reduced to only 1 or 2); $20.6 \%$ of the interviewees had never even considered direct-to-consumer marketing as an outlet for their products. These are mainly farmers who are also winegrowers, and members of a cooperative, which means they guarantee the sale of their production to local wine cooperatives.

Table 3 presents the characterisation of the 34 interviewees, their relation to the novelty (whether they adopted it, gave it up, or had never even considered it), their age group, university degree, and the crops mainly developed by them. Sequentially, Table 4 complements Table 3 by providing more detail on the reasons why farmers either stopped or kept developing the innovation. 
Table 3. Characterisation of the interviewees and their relationship with the innovation. Based on research data.

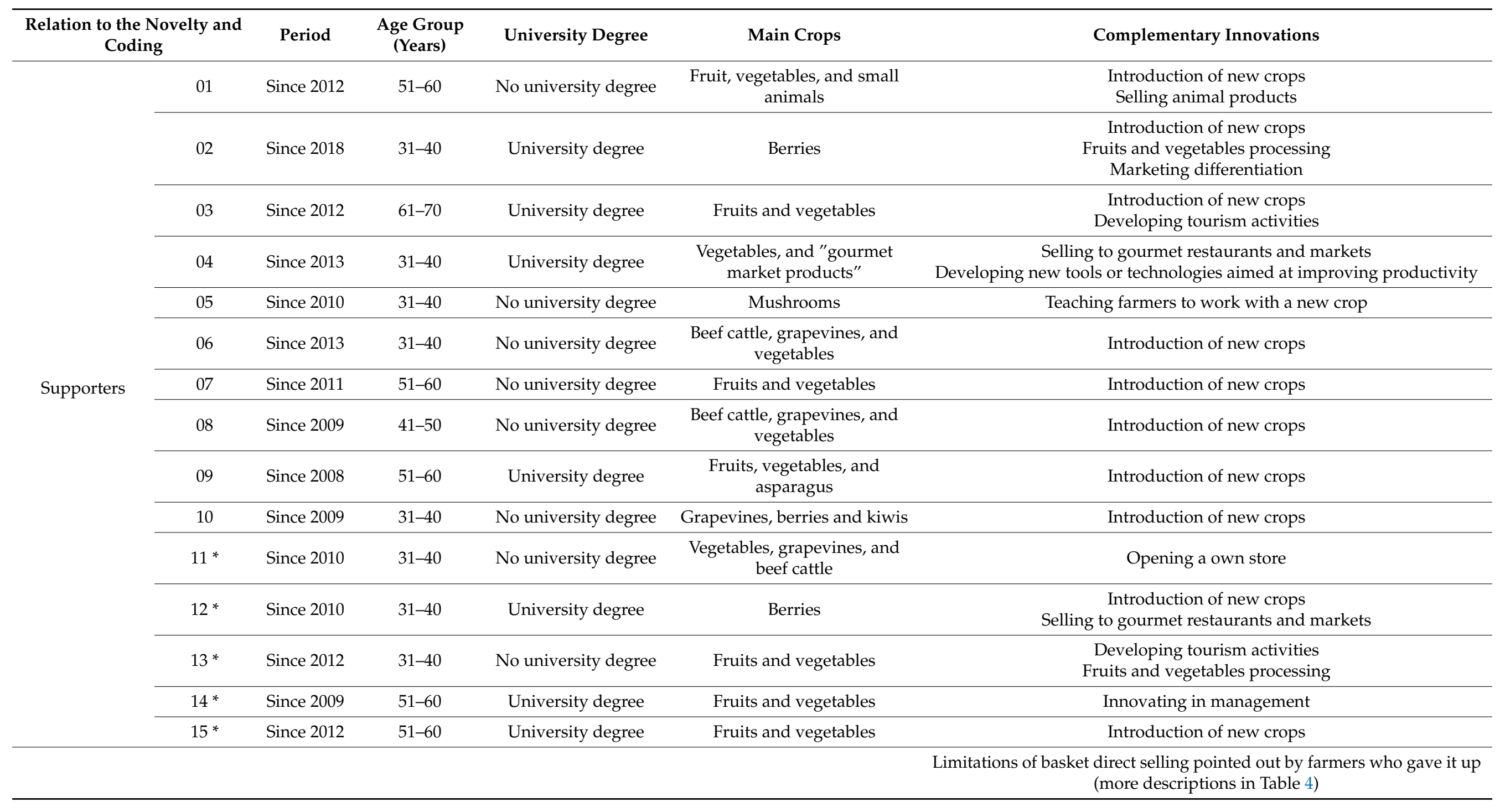


Table 3. Cont.

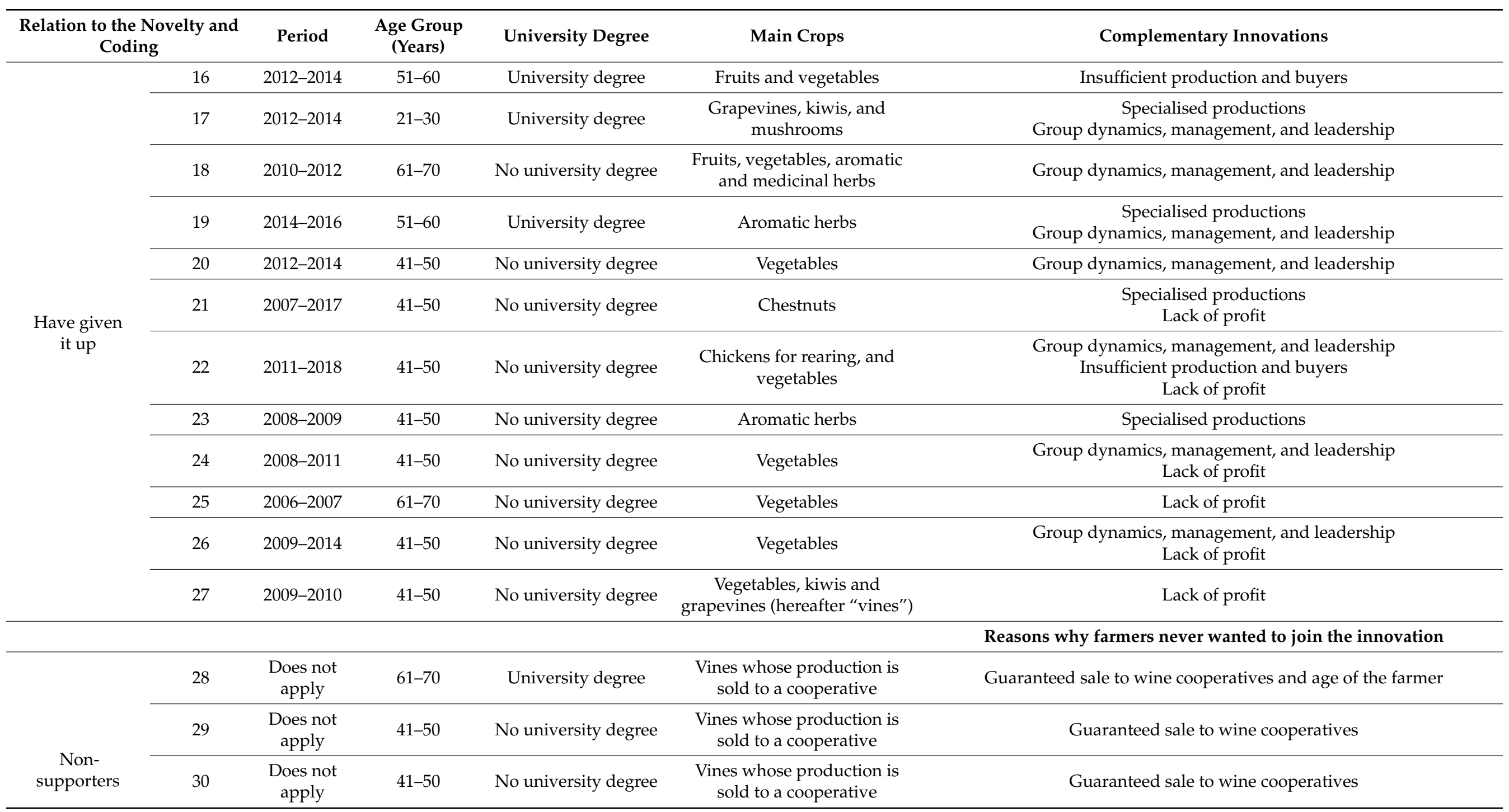


Table 3. Cont.

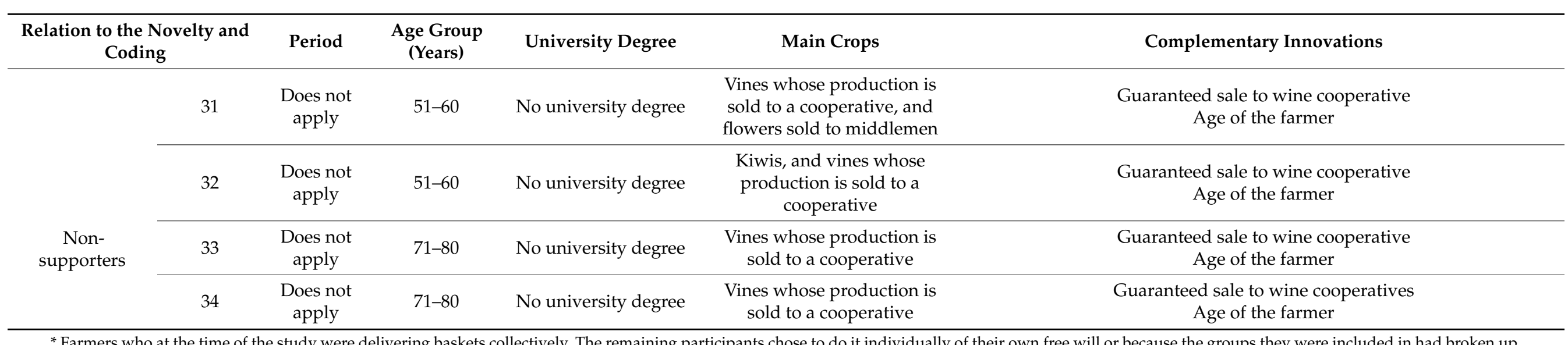

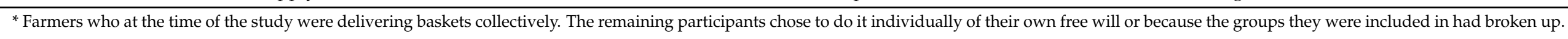

Table 4. Shortcomings of basket direct selling pointed out by farmers who gave it up. Based on narratives obtained during the field research stage.

\begin{tabular}{|c|c|c|}
\hline Limitations & Description & Narrative Extract \\
\hline Specialised productions & $\begin{array}{l}\text { The baskets included a few aromatic herbs and mushrooms. } \\
\text { Namely mushrooms were delivered in small quantities } \\
\text { although they represented a high percentage of the basket's } \\
\text { final cost. }\end{array}$ & $\begin{array}{l}\text { "In the case of Prove, I only produced mushrooms. I mean, it's one thing to add a product that, at } \\
\text { the time, cost five Euros per kilo, but quite another to add one kilo apples which cost sixty cents [ } \\
\text {.. ] If we look at the percentage, in a ten to fifteen Euro basket, [ . . ] ] for me it was already ten } \\
\text { percent, I get it. I get it that I was delivering a product which cost ten percent of the final price, } \\
\text { which is a lot, I know ... " (Interview 18). } \\
\text { "In my case, direct selling didn't mean much after all, and it didn't feel right, either; since I only } \\
\text { contributed with a very small amount, because I was only supplying aromatic herbs, I wasn't very } \\
\text { interested." (Interview 20). }\end{array}$ \\
\hline $\begin{array}{l}\text { Insufficient production } \\
\text { and buyers }\end{array}$ & $\begin{array}{l}\text { Basket inadequacy for customer food and gastronomic } \\
\text { preferences and demand, and customer failure to become } \\
\text { regular buyers. Additionally, competition from similar } \\
\text { products from other suppliers such as fairs and supermarkets. }\end{array}$ & $\begin{array}{l}\text { "But then, after a while, there are disadvantages to that basket-buying thing because it becomes a } \\
\text { routine, and after some time people are tired; they like to change, every now and then. In fact, after } \\
\text { two or three years, they begin to be a little fed-up." (Interview 23). } \\
\text { "Baskets are fewer because of the competition. Right now, many firms that have nothing to do with } \\
\text { Prove are increasing the supply of vegetables and advertise biologic vegetables that are not biologic } \\
\text { at all, but that they claim they are. So, this is a terrible mess." (Interview 19). }\end{array}$ \\
\hline
\end{tabular}


Table 4. Cont.

\section{Limitations}

\section{Description}

Disagreement, among participants, as to the program's underlying philosophies of supplying only seasonal produc and concentration of basket delivery in the hands of a few participants (who began acting as product brokers); Lack of time and preparation on the part of the farmers to deal in

Group dynamics, management, and leadership commercial activities, for instance not knowing how to handle customer complaints and demands; Lack of leadership that might have taken over the project after LDAs were no longer responsible for it; Lower acceptance of baskets in rural areas due to residents having, in some other way, access to fresh, organic, and seasonal products; Farmer difficulty transportin the baskets from production sites to distribution areas due to a lack of appropriate vehicles.

The small amounts that were delivered, besides the time

Profit limitations

\section{Narrative Extract}

"There must be trust between the people who supply the baskets [ ... ] sometimes that is a limitation because, deep down, we are responsible for the food security of a basket that is not only ours, and that may have its implications." (Interview 20).

"In the middle of all that, one or another producer would buy bananas and add them to the basket. Ok, let's not say bananas but goods ... Personally, I think that if I don't have the goods, it's no use inviting me because I am not going to invent them, but that is not how it goes with some people, they don't mind going to the market to buy or sell, but that doesn't work with me. People have to understand that if you don't have the product, you just don't; if you cannot supply the basket this week, you can't. "(Interview 21). "But there is always a producer who has the most responsibility, who monopolises and manages the group. As it happened with Prove, in the end, they decided what to add to the basket. And then, there is the greed." (Interview 17)

"Here, in Marco, the situation was different because it is a rural area, and most baskets were meant to Porto and Gaia. Ok, everybody has vegetables, everybody has a little of everything. Marco is a small town, and most baskets went to Porto, Vila Nova de Gaia, and that has costs. Nobody works for free; you have to pay for tolls, oil, and, at the end of the day, the business was not lucrative. "Interview 24).

"[ ... ] besides, everybody has an uncle, or a father-in-law who has a vegetable garden, so it is difficult to sell, unless, of course, you do something different [ . . . ]." (Interview 22).

"What was difficult for me was the distance, having a distribution point, and, at the same time, sustaining the project because I had to guarantee some income. I didn't produce enough vegetables and had to rely on other colleagues and all that logistics to ensure we had quality goods, especially biological ones. So, it became more and more difficult. "(Interview 19).

"It's just that everything is very fussy, and one spends much time on the road to deliver the baskets; in my case, I had no time to grow the goods. Perhaps there should be teams to deal with one thing and the other. Also, there were no clients. Let's say, perhaps, that the highest number of baskets I ever delivered was fifteen, seventeen, but mostly we did it as a favour, you know, to help out. And then, we were delivering seven, eight baskets, which is complicated. Five farmers delivered eight baskets ... " (Interview 21).

"As you know, the programme rests on delivering baskets, but the number of baskets I expected to need was small; therefore it was not worth my selling directly half a dozen kilos lettuce, half a dozen kilos tangerines or tomatoes ... (Interview 25). 
Farmers say that, in the beginning, basket direct selling was very well-received (a group of farmers used to deliver almost 300 baskets per week in the zone of Porto). Over time, factors like the breaking up of the groups ended up limiting the initiative's success, and indeed various narratives mention this. Table 4 presents a list of those factors, grouped according to the type of limitation, and some narrative extracts explaining why farmers gave up direct selling and the baskets project.

As can be seen, farmers usually mention more than one problem to account for their giving up the programme; however, market limitations, product inadequacy to respond consumer demand and low profitability are the most recurrent. Those having access to more urban areas like Porto and its surroundings somehow continued delivering basket direct selling even after groups had split up. They were able to ensure customer loyalty and maintain baskets as an important way of marketing their products. Regarding those farmers who chose to deliver their baskets to customers in small towns, they failed to ensure customer adherence. In these areas, people have other means to get fresh, quality goods at low prices due to resident strong bonds with agriculture and all things rural.

The data show that the experience of the farmers who ultimately gave up the programme lasted for two years. Groups began to split up, especially between 2010 and 2014, due to a lack of support, leadership, and clear guidelines, which caused farmers to have different understandings of how the novelty should be operationalised. Adopting the novelty also failed because of the particular crops being offered. Winegrowers were never particularly interested in direct-to-consumer marketing, given that they rely on the region's wine cooperatives to sell their product. The fact that many participants grow the same type of crops accounts for the absence of product diversity and a certain competition among farmers. Another constraint was crop seasonality. In conventional markets, consumers got used to having regular supplies of certain products and they demanded the same from farmers supplying the baskets. The latter, in an attempt to ensure customer loyalty and be able to offer baskets with various products, were forced to acquire them from conventional markets, thus corrupting the project's initial ideology.

The age of the farmers also influenced their decision to adopt or not adopt the innovation. Farmers who did not adopt it are, in general, older than those who adopt, including the innovation droppers. Having a university degree seems to be also associated with accepting the novelty and implementing it. While the group of farmers adopting it is composed of individuals with and without a university degree in the same proportion, among those who gave up the basket direct selling the number of farmers without a university degree is higher. The same is true in the case of the farmers who have never tried direct marketing. It seems to indicate that, at the time of the study, adherence and maintenance of direct marketing trough the basket scheme were associated with a set of skills and competencies acquired through qualifications.

This focus of this paper is the group composed of those who continued the activity, either collectively or individually, and are responsible for anchoring the novelty. In addition to possessing the necessary conditions (family support, a vehicle to transport goods, being in closer proximity to Porto's urban centre), they managed to continue implementing the novelty because they engaged a learning process to address it, thus developing parallel strategies to further develop the innovation. Often, baskets became attractive to farmers who kept their customers while the collective initiative was expanding, because they managed to innovate, departing from the novelty itself. In other words, keeping the basket direct selling initiative afloat required farmers to possess innovation capacity. In those cases that met with success, it is possible to say farmers proved to be capable of conjugating product innovation, service and marketing [59,60], aiming at overcoming the limitations previously mentioned (presented in Table 4). In 2014, Baptista, Cristóvão and Rodrigo [58] had already observed farmers were adapting to direct selling of baskets in the region when they began introducing new crops, implementing and adapting new technologies, expanding greenhouses and installing irrigation systems. In the course of the present study, 
a broader set of associated novelties was identified, which is listed and schematised in Figure 3.

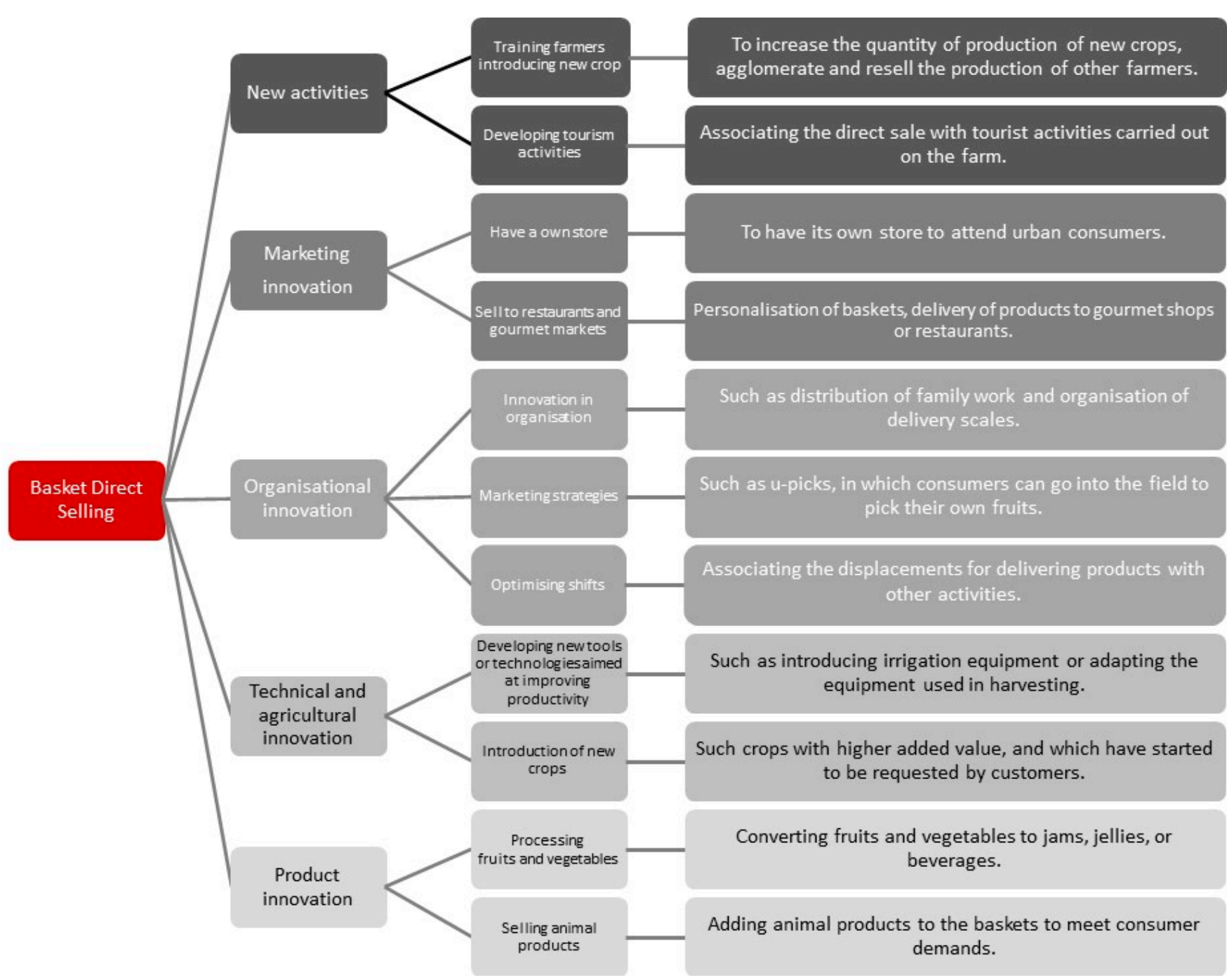

Figure 3. Schematic representation of basket direct selling-associated novelties mobilised by farmers adopting the initiative. Based on research data.

Figure 3 shows a list of innovations adopted by farmers to allow continuing selling baskets directly to consumers. Innovations were grouped according to their typology as follows: diversifying activities in the farm; marketing innovations; organizational innovations; product innovations. These complementary innovations enabled successful adopters overcoming and easing the reported constraints that lead many to abandon the innovation. This innovation strategy of complementing direct marketing with a series of technological and non-technological innovations lead by farmers themselves was a response to survive to the end of support by the LDAs. Adopters' business became unprotected innovation niches and they have to entail new innovation strategies, where education degree and younger age favored.

The high rate of innovation dropping highlights that a support system was needed, including farm advisory able to deliver advice on logistic and legal issues and to help farmers to develop collaborative arrangements fitting-in the direct marketing specificities in the study region (contextual features). It is worth mentioning that the innovations presented in Figure 3 may have been developed individually or through a consortium, in different combinations, aiming at differentiating innovators products from those sold in conventional markets or even to make baskets more profitable. 


\section{Discussion}

The main reason underlying farmer adherence to the novelty was the opportunity it represented to sell their production surplus. Meanwhile, it took them six months to one year to prepare themselves and acquire the necessary knowledge to join the programme. Probably, they were not expected to have many qualifications and skills to act collaboratively in direct-to-consumer marketing. Given the high number of farmers who quit the programme, it is fair to assume the six month-to-one-year period of learning and preparation was not enough for farmers to know and accept it. Besides, the product they were offering did not have the necessary differentiation (regarding either the type of goods offered or other attractive aspects) to compete with other forms of food consumption and distribution, nor did it reach the right momentum to become economically sustainable for many of the early adopters.

As it has already been mentioned, not all the farmers adapted to the fruit and vegetable basket direct selling model (due to various reasons such as type of crops, management of labour to ensure production, distribution, and sales; availability of a vehicle to make deliveries; ability to attract and manage clients, and adapt to their needs). While for those who quit, the model represented profit losses, for those who kept on, it was a means of establishing connections with consumers and obtaining differentiated income. In a study published in 2014, regarding basket delivery in the area under survey, Baptista, Cristóvão, and Rodrigo [58] had come across an average income of approximately four hundred and seventy-eight Euros a month per farmer, varying from a minimum of hundred and fifty-seven Euros to a maximum of one thousand, five hundred and ninety-three Euros. In this sense, the farmers who maintained the basket direct selling activity did not have insignificant profits. Besides, they took advantage of the contact with customers, using it as a learning strategy, while creating new ways to present their products or associate them with services in order to make them more differentiated and attractive. [51,58].

In terms of MLP, one can say the basket direct selling initiative in the study region illustrates a novelty that had its incubation niche in the LDAs. After this novelty somehow stopped being managed by the LDAs, the transition path also stopped growing. Moreover, the novelty anchored to the regime only marginally because only some of the farmers composing the initial group kept delivering the baskets, and only a few customers continued buying them. Several aspects may account for the transition failure. They can be addressed from the MLP perspective, in terms of the sociotechnical levels, or the Types of Anchoring and Three Interrelated Analytic Dimensions one, looking into the case from the institutional elements and actors involved.

The first aspect that stands out is the exogenous question of innovation. The novelty was proposed by a European Community initiative and met with success in other metropolitan areas, which led to the recognition and praise of the baskets project. The PROVE received the following recognitions, considered: Project of the Month by the European Rural Network; High potential Social Entrepreneurship Initiative by the IES (Social Entrepreneurship Institute); first place in the category of "Support to the development of ecological markets and resource efficiency" in the 10th edition of the European Enterprise Promotion Awards. It was also selected to represent Portugal in the European Conference on Rural Development in Cork, Ireland, and chosen by INHERIT as a promising European agricultural and environmentally sustainable practice [61]. However, the implementation of the novelty in places away from urban settlements without a more detailed evaluation showed the basket direct selling initiative's inadequacy to foster an agri-food transition in the study region, despite it being classified as an intermediated region and being close to a metropolitan area (Porto city conurbation).

The second question consists of the analogy that can be established between the innovation niche and the LDAs. Assuming that niches are innovation incubation loci capable of progressing regardless of the regime's direct pressure, one accepts LDAs operate as such. When basket direct selling enters the regime as goods in search of a market, they lose in structuring, and the experience collapses. Besides, when farmers become 
responsible for managing the novelty, the groups become weaker and start breaking up, thus contributing to the novelty's regressive pathway.

From this point on, a marginal anchoring process begins to take place. Under some conditions, only some farmers (farmers codded as 1-10, introduced in Table 3), who had innovation skills, were able to anchor the exogenous innovation to their practices, knowledge, and routines, thus adapting it to their realities and keeping it alive. In this case, basket direct selling represents a novelty that in the niche-to-regime permeability anchors only to some points due to the link between innovations. On the other hand, they show farmer innovation skills since these can join other network participants and develop a process of innovation creation that differentiates and maintains the anchoring points [62]. This innovation adequacy, linking it to other innovations, stands out because, in 2018, of the initial group working collectively, only five farmers are still participating in the programme. The rest chose to assemble and deliver the baskets individually. These findings are in keeping with Hultine, Cooperland, and Curry's observations (2007) [63] that the success for developing local food systems depends on farmers' specific skills, their dynamics, creativity, competence, good communication, and relationship with other actors and entities, as well as persistence to build a relationship of trust with consumers.

Regarding the analysis of the socio-technical landscape, there are pressures and transformation trends that influence the other two levels. While the niche tended to accommodate this aspect, the regime was characteristically rigid and stable, given that only a tiny market segment was mobilised, represented by the few loyal consumers. However, on the one hand, are consumers interested in the basket direct selling philosophy while, on the other hand, the proposal generally did not fit the majority's demands. The weak adherence of the regime to the innovation was not enough to induce a full, lasting integration but rather a marginal anchoring. Within the Three Interrelated Analytic Dimensions and Types of Anchoring, namely in what concerns the institutional question (rules, and cognitive, interpretative, normative, and economic institutions), the following stand out:

Some farmers reported a lack of contractual instruments to participate in the basket direct selling initiative, as well as clear rules to operate it;

It appears there were no strategies to ensure product origin and quality control, which created an impression of disrepute among consumers and members of the niche themselves. Therefore, in this type of innovation, the proposal of initiatives is not enough. It is necessary to create effective structures for innovations to last and institutionally adapt over time;

Those farmers who succeed in assimilating the new cognitive and interpretative framework, and engaged in the basket direct selling programme, used it as a learning strategy to a goal, a springboard to create and operationalise other innovations.

In turn, human factors (networks, actors, organisations, and social groups) structured and developed around innovation also exhibited some weaknesses:

Farmers lacked a leadership that would coordinate the initiative after LDAs ceased to do so;

At a particularly busy period, one of the groups tried to expand the delivery area and get a larger market share. This attitude, representing the expression of the group's self-organisation, did not meet with the approval of the Local Development Association in charge that put an end to it.

Despite some previous briefings on the philosophy and functioning of the basket direct selling, it appears that farmers were not qualified enough to work collaboratively. Given the high number of farmers who gave up the initiative, and according to their evaluation, it is fair to assume they did not possess the necessary decision-making criteria.

Figure 4 schematically lists Three Interrelated Analytic Dimensions and Types of Anchoring sociotechnical elements representing anchoring in the MLP. 


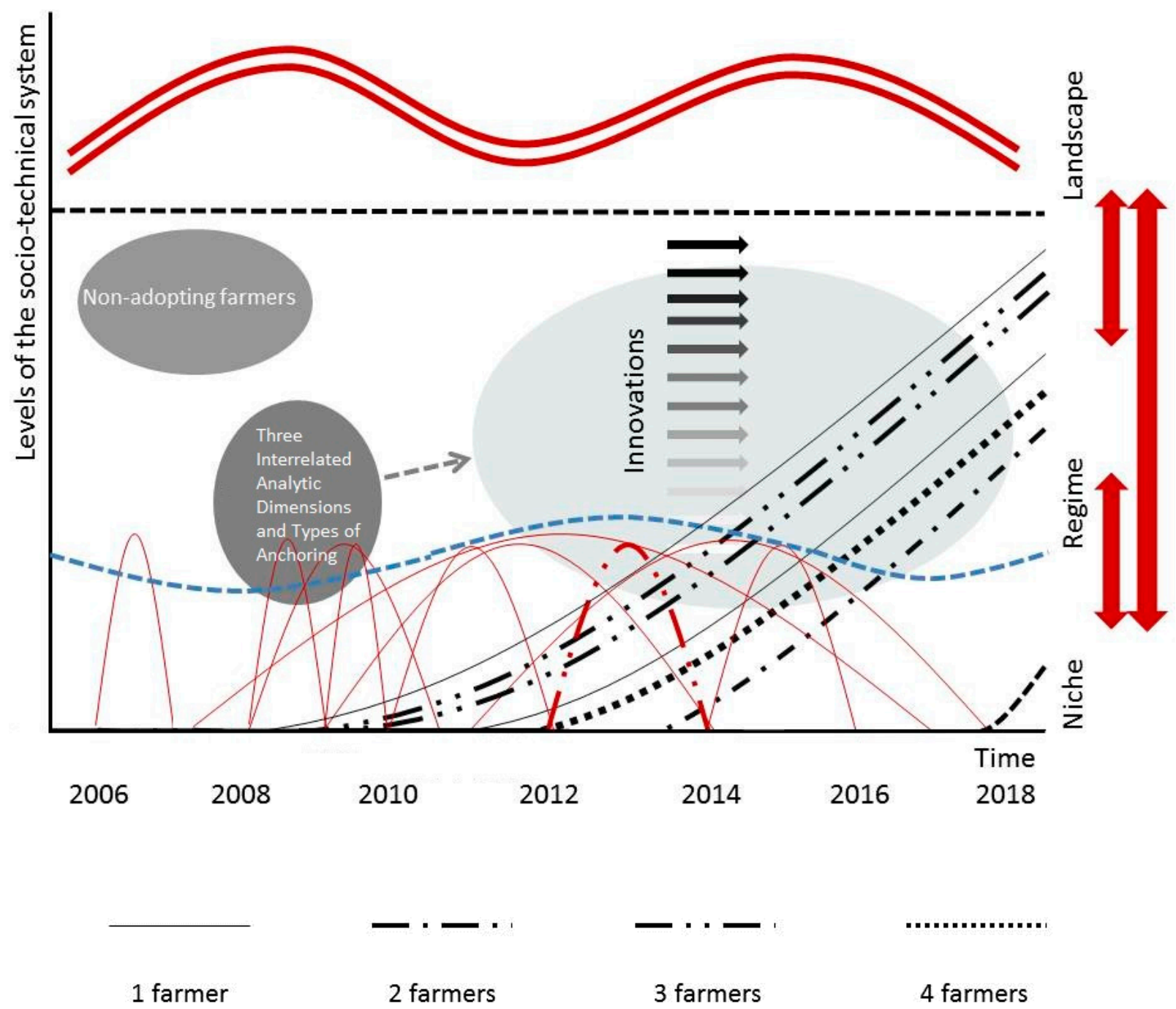

Figure 4. Individual pathways of basket direct selling innovation under MLP in a sociotechnical system, showing the influence of other innovations and of Types of Anchoring and Three Interrelated Analytic Dimensions on anchoring.

The scheme in Figure 4 shows the sociotechnical system under survey, composed of its conceptual levels of niche, regime, and landscape. Next, we will look into its dynamism from basket direct selling anchoring and Three Interrelated Analytic Dimensions and Types of Anchoring development.

First, it should be pointed out that the novelty studied was born out of a European initiative, which characterises it as exogenously concerning the system where it was applied. It, therefore, indicates the presence of a landscape movement over the dynamics of the sociotechnical system in question. Bearing in mind that the basket direct selling model was conceived externally to the local regime, it follows that LDAs and the farms adopting the novelty worked as incubation niches. Regarding the regime, first, it includes the group of farmers who chose not to participate (represented in dark grey) due to their being suppliers of local cooperatives, and so, part of an already established regime. Besides, the regime did not help the anchoring of the novelty much, neither in terms of rules and institutions nor within the human actor framework (Three Interrelated Analytic Dimensions and Types of Anchoring).

Three Interrelated Analytic Dimensions and Types of Anchoring are represented by a grey eliptical form. They slightly influence the anchoring process, pictured here through a discontinuous grey arrow. They cross the regime level because, as mentioned before, LDAs, also acting institutionally in the regime, in this case, somehow operated as innovation niches. 
Basket direct selling links to the regime represents an anchoring process, depicted here in the shape of a light grey ellipse. The phenomenon may be described as anchoring because it relies on a weak adherence of elements from the niche and the regime. This weak adherence may even cause the novelty to go back in its path and gradually disappear in the region in question. However, this anchoring only happens because the farmers, still engaged in direct-to-consumer marketing and interested in keeping it alive, gathered their skills to innovate from other innovation examples. They endowed their baskets with artifacts that made them more linked to the regime, and, at the same time, more prone to face the latter's rigidity. These other innovations represent various practices and strategies, and each farmer may have resorted to more than one to keep supplying the baskets. They are represented in Figure 4 by horizontal arrows illustrating the anchoring process. This integration of an array of innovations may have been farmers' response to Three Interrelated Analytic Dimensions and Types of Anchoring failure to develop the basket direct selling initiative. In the absence of support from actors and institutions, farmers came up with alternative solutions to continue selling their baskets directly to consumers.

The niche-regime interface is represented by a discontinuous wavy curve drawn in blue. It appeared to be the best way to picture its permeability and the exchanges that exist between levels. Also, it indicates this interface may have a peculiar, non-static dynamism, full of action-reaction movements and instability of a level towards another. The best way to capture it is to analyse the individual pathways of adopting or giving up the novelty, here represented by curves drawn in red for farmers who were no longer engaged in direct marketing at the time of the survey and in black for those who continued to do it. Thus, the lines in black refer to pathways that had some anchoring, thanks to the support of other innovations. One of the pathways, beginning in 2018, is a dotted line because it describes the uncertain path of the farmer from the date of the interview.

Successful pathways of adopting the novelty overlap unsuccessful ones. In general, the former began to happen after 2010. However, the farmers who adhered to the initiative from the very beginning did not have the same results, which shows it had to be tested regionally, besides confirming the roles of LDAs and farms as experimentation niches. Moreover, although overlapping, pathways differ, indicating that locally, there was a dissemination and learning process regarding the novelty. Those who adhered at a later stage certainly had previous knowledge from farmers that had quit the programme regarding the positive and negative aspects of basket direct selling. Thus, despite the weakness of the Three Interrelated Analytic Dimensions and Types of Anchoring component, there are informal exchanges of content, experiences, information, and knowledge between farmers and it allowed the novelty to last in the study area for 12 years.

\section{Conclusions}

Specialised literature often argues the direct buying of local products resulting in short food supply chains (SFSCs) is an important strategy for the survival of farmers who cannot compete in larger-scale markets [64]. The present study looked into a SFSC experience in northwest Portugal and shows there may be limitations to the success of this strategy.

The study focused on contributing to map anchoring situations in need of further scientific research. The case studied portrays a situation not yet described in the literature in which niche innovations manage to survive in the regime's marginal zone by adhering to it thanks to the articulation between innovations.

Farmer experience regarding the basket direct selling programme reflects the existence of anchoring conditions because, in this case, the novelty did not change all the regime's aspects, attracting only some of its customers. The novelty's future path is marked by uncertainty regarding its survival. It may develop and become more successful, or it may fail to overcome the regime, in which case it will decline and disappear. Contrarily [9], it may perpetuate itself in the MLP levels versus time representation between niche and regime as a marginal anchoring. For now, basket direct selling remains an innovation that has achieved weak actor anchoring and little institutional anchoring in the study region. 
Yet, even if the direct selling of baskets does not promote a transition, it is, nevertheless, important for farmers who earn income from it. In the long term, however, and thinking that the innovation when launched to the regime no longer belongs, conceptually, to the niche, we can think that this threshold "space X time", between niche and regime, may offer an opportunity for innovation to mature. Thus in the future, it may find promising conditions to resurface.

The lifespan of basket direct selling is related to farmer innovation skills. Not being able to change the regime or get its support, farmers found ways to anchor to it, obtaining market benefits according to their interests and productive skills. Because of the novelty's exogenous quality, which prevented the initiative from developing locally, farmers felt motivated to associate it with other innovations. It was a sort of "cross-pollination" combining knowledge and learning, as suggested by Zurbriggen, and Sierra (2017) [53]. Thus, on the one hand, the novelty's exogenous quality limited its reach, while on the other hand, it reflects the regimes' heterogeneity. Even when regimes fail to fully incorporate innovations, they have a market component which accommodates them, albeit marginally.

The present study shows that the novelty's reach concerning scale and scope to generate a transition (as suggested by Three Interrelated Analytic Dimensions and Types of Anchoring) depends on institutional and actor dimensions for linking and overlapping innovations to the regime. These findings may help decision makers formulate better innovation and political proposals regarding transitions for future implementation that also entail changes in actors and institutional conditions.

From the viewpoint of anchoring, the study contributes to mapping yet another typology that places the niche-regime interface in a configuration of innovation overlapping, in which one strengthens the other so that they can endure. The phenomenon points to dynamism in the said interface and shows that the threshold between levels may not be so clear and stable. This dynamic interface is rich in events that may be further developed to improve the MLP and the anchoring. Not only has a different type of anchoring been identified, but many others are likely to be described, which will no doubt broaden the research on these events. Identifying these typologies is essential if one wishes to understand innovation pathways from their conception. Studies should also look into the dynamics that may occur in the niche-regime interface since, from the moment the levels and anchoring are conceptualised, they may seem more static than they are and marked by the regime's perviousness and imperviousness to niche innovations. The present study suggests the niche-regime relationship may occur under many other patterns; therefore, mapping them must continue. In doing so, by trying to understand how innovations anchor to each other, one may help them develop positively and boost the intended transition.

Although the novelty did not meet with much success, a significant group of farmers has embarked on the programme and has exchanged knowledge and learning experiences so expressively that since 2008 it has been spreading through the local socio-technical tissue, trying to anchor to it. In fact, on the threshold of the niche-regime interaction, the project's initial expectations were not generally met. Farmers expected to sell their products and generate a higher income, which did not happen.

In this case, SFSC did not induce a transition. Unlike technological innovations, innovations like the basket direct selling, when operating on complex regimes like the agri-food one, need constant renewal and adequacy to the market's oscillation demands. It may require a more dynamic concept of a niche than merely an incubator of innovations that may or may not be incorporated by the regime in a given context at a given moment. Therefore, niches must be both of the following: 1 . evolutionary and dynamic and capable of constantly qualifying innovations; and 2. articulators, managing to link innovations from various niches to provide adequate responses in collaborative contexts operating in complex landscapes and regimes. Additionally, of course, developing the skill to count on the participation of institutions and actors (Three Interrelated Analytic Dimensions and Types of Anchoring) to better place innovations regarding their linking to the regime before they even begin to show their weaknesses. It should be noted that, in this case study, the 
innovation was not radical in nature. Therefore, it did not have the potentiality to cause radical changes in the regime. The intention of the members was only to make an outflow of their productive surplus. This allows the niches to be characterised as having only the potential to exist on the margins of the regime.

Hence, Three Interrelated Analytic Dimensions and Types of Anchoring are crucial to a successful transition and to help innovations face highly stable regimes. Failure to grant appropriate support from actors and institutions caused the anchoring to be weak and the novelty to decline slightly. It is possible to say this weakness was also responsible for farmers mobilising other innovations. They did it alongside the direct selling of baskets, which resulted in their better anchoring and survival, either as a result of their calls to a differentiated product or their increase of productivity and competitiveness. In a way, mobilising innovations appeared as a strategy adopted by some farmers to deal with Three Interrelated Analytic Dimensions and Types of Anchoring weaknesses revealed along with the programme. It is also a means of making up for the lack of institutional support and articulation, the right adherence of actors, and the appropriateness of exogenous innovations to a new application environment. Those farmers who failed to find the necessary strategies to make up for the lack of support ended up giving up the novelty. On the contrary, at least to a group of farmers, the initiative paid out, although they had to work alone. Studying these "pollination" phenomena from the perspective of MLP may be a field worth exploring.

However, even if our study suggests that there may be specificities in the processes of innovation development and anchorage, we imagine that similar anchorages may be repeated elsewhere. This is especially so if the innovation possesses a design character that is exogenous to the regime in which it is deployed, and if part of the supporters mobilise their skills and resources to keep alive an innovation that brings them benefits, even if it is in the regime's threshold environment. Our sample of interviewed farmers originated from a purposive logic. It was not intended to be representative. Although by the end of the interviews we had interviewed practically all the farmers who were, or had been, involved in the development of the innovation in the study region, it is possible that a greater diversity of non-supporters could have provided us with new information.

Future studies on this subject should carry out in-depth research to explain the relationship between the skills farmers possess and their knowledge of skills that would allow them to innovate and thus take them in a different direction from the one originally planned. Moreover, further studies on anchoring should be developed to identify other cases likely to reveal unexpected innovation pathways and marginal survival strategies that can add a peculiar dynamism to the niche-regime interface so vital for the success of a transition. Also, an evaluation of how similar innovations may occur in the study area is indispensable, looking into the reasons underlying the failure of the basket direct selling initiative, given that people invested money and skills on the programme and the agri-food system still needs sustainable solutions.

Author Contributions: Conceptualization, F.S.P. and L.M.; Investigation, F.S.P. and L.M.; Methodology, F.S.P. and L.M.; Supervision, L.M.; Writing—original draft, F.S.P. and L.M.; Writing-review \& editing, L.M. All authors have read and agreed to the published version of the manuscript.

Funding: This research was funded by AgriLink-Agricultural Knowledge: Linking farmers, advisors and researchers to boost innovation project, funded by Horizon 2020-Grant Agreement $\mathrm{n}^{\circ} 727577$. English proofreading of the article was supported by national funds, through the FCT-Portuguese Foundation for Science and Technology, under the project UIDB/04011/2020.

Institutional Review Board Statement: The research in this paper has followed the ethical standards of the H2020 AgriLink project, which are consistent with ethical standards and guidelines of Horizon 2020.

Informed Consent Statement: Informed consent was obtained from all subjects involved in the study.

Conflicts of Interest: The authors declare no conflict of interest. 


\section{References}

1. Rip, A.; Kemp, R. Towards a theory of sociotechnical change. In Human Choice and Climate Change; Rayner, S., Majone, E.L., Eds.; Battelle Press: Columbus, OH, USA, 1998; pp. 327-399.

2. Berkhout, F.; Smith, A.; Stirling, A. Socio-technical regimes and transition contexts. In System Innovation and the Transition to Sustainability; Elzen, B., Geels, F., Green, K., Eds.; Edward Elgar Publishing Ltd.: Cheltenham, UK, 2004; pp. 48-75.

3. Geels, F.W.; Schot, J. Typology of sociotechnical transition pathways. Res. Policy 2007, 36, 399-417. [CrossRef]

4. Geels, F.W. Technological transitions as evolutionary reconfiguration processes: A multi-level perspective and a case-study. Res. Policy 2002, 31, 1257-1274. [CrossRef]

5. Demartini, E.; Gaviglio, A.; Pirani, A. Farmers' motivation and perceived effects of participating in short food supply chains: Evidence from a North Italian survey. Agric. Econ. 2017, 63, 204-216.

6. GPP—Gabinete de Planeamento, Políticas e Administração Geral. Available online: http://www.gpp.pt/images/Agricultura/ Estatisticas_e_Analises/Estatisticas / AnaliseEstruturaExplAgricolas2016.pdf (accessed on 2 August 2021).

7. Madureira, L.; Mucha, T.; Barros, A.B.; Marques, C. The Role of Advisory Services in Farmers' Decision Making for Innovation Uptake. Insights from Case Studies in Portugal; UTAD: Vila Real, Portugal, 2019; pp. 1-86.

8. Smith, A. Translating Sustainabilities between Green Niches and Socio-Technical Regimes. Technol. Anal. Strat. Manag. 2007, 19, 427-450. [CrossRef]

9. Elzen, B.; van Mierlo, B.; Leeuwis, C. Anchoring of innovations: Assessing Dutch efforts to harvest energy from glasshouses. Environ. Innov. Soc. Transit. 2012, 5, 1-18. [CrossRef]

10. Bui, S.; Cardona, A.; Lamine, C.; Cerf, M. Sustainability transitions: Insights on processes of niche-regime interaction and regime reconfiguration in agri-food systems. J. Rural Stud. 2016, 48, 92-103. [CrossRef]

11. Slingerland, M.; Schut, M. Jatropha Developments in Mozambique: Analysis of Structural Conditions Influencing Niche-Regime Interactions. Sustainability 2014, 6, 7541-7563. [CrossRef]

12. Geels, F. From sectoral systems of innovation to socio-technical systems: Insights about dynamics and change from sociology and institutional theory. Res. Policy 2004, 33, 897-920. [CrossRef]

13. El Bilali, H. The Multi-Level Perspective in Research on Sustainability Transitions in Agriculture and Food Systems: A Systematic Review. Agriculture 2019, 9, 74. [CrossRef]

14. Hinrichs, C.C. Transitions to sustainability: A change in thinking about food systems change? Agric. Human. Values 2004, 31, 143-155. [CrossRef]

15. Sovacool, B.K.; Hess, D.J. Ordering theories: Typologies and conceptual frameworks for sociotechnical change. Soc. Stud. Sci. 2017, 47, 703-750. [CrossRef]

16. Rotmans, J.; Kemp, R.; van Asselt, M.; Geels, F.; Verbong, G.; Molendijk, K. Transities en Transitiemenagement: De Casus van een Emissiearme Energievoorziening; ICIS/MERIT: Maastricht, The Netherlands, 2000; pp. 1-123.

17. López-García, D.; Calvet-Mir, L.; Di Masso, M.; Espluga, J. Multi-actor networks and innovation niches: University training for local Agroecological Dynamization. Agric. Hum. Values 2018, 36, 567-579. [CrossRef]

18. Geels, F. The multi-level perspective on sustainability transitions: Responses to seven criticisms. Environ. Innov. Soc. Transit. 2011, 1, 24-40. [CrossRef]

19. Oliveira, D.; Gazolla, M.; de Carvalho, C.X.; Schneider, S. A produção de novidades: Como os agricultores fazem para fazer diferente? In Os Atores do Desenvolvimento Rural: Perspectivas Teóricas e Práticas Sociais; Schneider, S., Gazolla, M., Eds.; Editora da UFRGS: Porto Alegre, Brazil, 2011; pp. 91-116.

20. Konefal, J. Governing Sustainability Transitions: Multi-Stakeholder Initiatives and Regime Change in United States Agriculture. Sustainability 2015, 7, 612-633. [CrossRef]

21. Roep, D.; Van Der Ploeg, J.; Wiskerke, J. Managing technical-institutional design processes: Some strategic lessons from environmental co-operatives in the Netherlands. NJAS-Wagening. J. Life Sci. 2003, 51, 195-217. [CrossRef]

22. Wigboldus, S.; Klerkx, L.; Leeuwis, C.; Schut, M.; Muilerman, S.; Jochemsen, H. Systemic perspectives on scaling agricultural innovations: A review. Agron. Sustain. Dev. 2016, 36, 46. [CrossRef]

23. Seoane, M.V.; Marín, A. Transiciones hacia una agricultura sostenible: El nicho de la apicultura orgánica en una cooperativa Argentina. Mundo Agrar. 2017, 18, e049. [CrossRef]

24. Hargreaves, T.; Longhurst, N.; Seyfang, G. Up, down, round and round: Connecting regimes and practices in innovation for sustainability. Environ. Plan. A 2013, 45, 402-420. [CrossRef]

25. Loeber, A. Inbreken in Het Gangbare Transitie-Management in de Praktijk: De NIDO-Benadering; NIDO: Leeuwarden, The Netherlands, 2003; pp. 1-85.

26. Geels, F. The dynamics of transitions in socio-technical systems: A multi-level analysis of the transition pathway from horse-drawn carriages to automobiles (1860-1930). Technol. Anal. Strateg. Manag. 2005, 17, 445-476. [CrossRef]

27. Geels, F.W. Major system change through stepwise reconfiguration: A multi-level analysis of the transformation of American factory production (1850-1930). Technol. Soc. 2006, 28, 445-476. [CrossRef]

28. Ingram, J. Framing niche-regime linkage as adaptation: An analysis of learning and innovation networks for sustainable agriculture across Europe. J. Rural Stud. 2015, 40, 59-75. [CrossRef]

29. Ingram, J.; Maye, D.; Kirwan, J.; Curry, N.; Kubinakova, K. Interactions between Niche and Regime: An Analysis of Learning and Innovation Networks for Sustainable Agriculture across Europe. J. Agric. Educ. Ext. 2015, 21, 55-71. [CrossRef] 
30. Diaz, M.; Darnhofer, I.; Darrot, C.; Beuret, J.E. Green tides in Brittany: What can we learn about niche-regime in-teractions? Environ. Innov. Soc. Transit. 2013, 8, 62-75. [CrossRef]

31. Sutherland, L.-A.; Peter, S.; Zagata, L. Conceptualising multi-regime interactions: The role of the agriculture sector in renewable energy transitions. Res. Policy 2015, 44, 1543-1554. [CrossRef]

32. Vankeerberghen, A.; Stassart, P.M. The transition to conservation agriculture: An insularization process towards sustainability. Int. J. Agric. Sustain. 2016, 14, 392-407. [CrossRef]

33. Belmin, R.; Meynard, J.M.; Julhia, L.; Casabianca, F. Sociotechnical controversies as warning signs for niche governance. Agron. Sustain. Dev. 2018, 38, 44. [CrossRef]

34. Schiller, K.; Godek, W.; Klerkx, L.; Poortvliet, P.M. Nicaragua's agroecological transition: Transformation or recon-figuration of the agri-food regime? Agroecol. Sustain. Food Syst. 2020, 44, 611-628. [CrossRef]

35. Carlsson, B.; Stankiewicz, R. On the nature, function and composition of technological systems. J. Evol. Econ. 1991, 1, 93-118. [CrossRef]

36. Scott, W.R. Institutions and Organizations; Sage Publication: Thousand Oaks, CA, USA, 1995; pp. 1-178.

37. Smith, A.; Stirling, A.; Berkhout, F. The governance of sustainable socio-technical transitions. Res. Policy 2005, 34, 1491-1510. [CrossRef]

38. Baptista, A.; Cristóvão, A.; Rodrigo, I.; Tibério, L. Relatório Final de Avaliação do Projecto de Cooperação Interterritorial Prove-Promover e Vender. A Perspectiva dos Actores e Equipa de Trabalho; ISA-UTL e UTAD: Portugal, 2012; pp. 1-67.

39. Ader-Sousa. Available online: https://www.adersousa.pt/iniciativas/prove/ (accessed on 31 January 2021).

40. Dolmen. Available online: https://www.dolmen.pt/ (accessed on 31 January 2021).

41. Kneafsey, M.; Venn, L.; Schmutz, U.; Balázs, B.; Trenchard, L.; Eyden-Wood, T.; Bos, E.; Sutton, G.; Blackett, M. Short Food Supply Chains and Local Food Systems in the EU. A State of Play of Their Socio-Economic Characteristics; Joint Research Centre: Seville, Spain, 2013; pp. 1-128. Available online: https:/ / op.europa.eu/en/publication-detail/-/publication/d16f6eb5-2baa-4ed7-9ea4-c6dee7 080acc/language-en (accessed on 1 December 2021).

42. Renting, H.; Marsden, T.K.; Banks, J. Understanding Alternative Food Networks: Exploring the Role of Short Food Supply Chains in Rural Development. Environ. Plan. A 2003, 35, 393-411. [CrossRef]

43. Todorovic, V.; Maslaric, M.; Bojic, S.; Jokic, M.; Mircetic, D.; Nikolicic, S. Solutions for More Sustainable Distribution in the Short Food Supply Chains. Sustainability 2018, 10, 3481. [CrossRef]

44. Niemi, P.; Pekkanen, P. Estimating the business potential for operators in a local food supply chain. Br. Food J. 2016, 118, $2815-2827$. [CrossRef]

45. Kumar, V.; Wang, M.; Kumari, A.; Akkaranggoon, S.; Garza-Reyes, J.A.; Neutzling, D.; Tupa, J. Exploring short food supply chains from Triple Bottom Line lens: A comprehensive systematic review. In Proceedings of the International Conference on Industrial Engineering and Operations Management Bangkok, Bangkok, Thailand, 5-7 March 2019; pp. 728-738. Available online: http:/ /ieomsociety.org/ieom2019/papers/216.pdf (accessed on 1 December 2021).

46. Bellec-Gauche, A.; Chiffoleau, Y.; Maffezzoli, C. Glamur Project Multidimensional Comparison of Local and Global Fresh Tomato Supply Chains; INRA: Montpellier, France, 2015; pp. 1-56.

47. Ogier, M.; Cung, V.-D.; Boissière, J. Design of a Short and Local Fresh Food Supply Chain: A Case Study in Isère. In International Workshop on Green Supply Chain (GSC). In Proceedings of the ROADEF-15ème Congrès Annuel de la Société Française de Recherche Ppérationnelle et d'aide à la Decision, Arras, France, 26-28 February 2014; pp. 1-11. Available online: https: / / hal.univ-smb.fr/hal-01009391/ (accessed on 1 December 2021).

48. Malak-Rawlikowska, A.; Majewski, E.; Wąs, A.; Borgen, S.O.; Csillag, P.; Donati, M.; Freeman, R.; Hoàng, V.; Lecoeur, J.-L.; Mancini, M.C.; et al. Measuring the Economic, Environmental, and Social Sustainability of Short Food Supply Chains. Sustainability 2019, 11, 4004. [CrossRef]

49. Vittersø, G.; Torjusen, H.; Laitala, K.; Tocco, B.; Biasini, B.; Csillag, P.; De Labarre, M.D.; Lecoeur, J.-L.; Maj, A.; Majewski, E.; et al. Short Food Supply Chains and Their Contributions to Sustainability: Participants' Views and Perceptions from 12 European Cases. Sustainability 2019, 11, 4800. [CrossRef]

50. Ziegler, R. Social innovation as a collaborative concept. Innov.-Eur. J. Sci. Res. 2017, 30, 388-405. [CrossRef]

51. Barradas, L.C.S.; Rodrigues, E.M.; Pinto-Ferreira, J.J. Supporting Collaborative Innovation Networks for New Concept Development through Web Mashups. In Risks and Resilience of Collaborative Networks; Camarinha-Matos, L., Bé-naben, F., Picard, W., Eds.; Springer: Cham, Switzerland, 2015; pp. 357-365.

52. Lundvall, B.-A.; Borrás, S. Science, Technology and Innovation Policy. In The Oxford Handbook of Innovation; Fagerberg, J., Mowery, D.C., Richard, R.N., Eds.; Oxford University Press: Oxford, UK, 1998; pp. 599-631.

53. Zurbriggen, C.; Sierra, M. Innovación colaborativa: El caso del Sistema Nacional de Información Ganadera. Agrociencia Urug. 2017, 21, 140-152.

54. Rogers, E.M. Diffusion of Innovations; Free Press: New York, NY, USA, 2010; pp. 1-526.

55. Biernacki, P.; Waldorf, D. Snowball Sampling: Problems and Techniques of Chain Referral Sampling. Sociol. Methods Res. 1981, 10, 141-163. [CrossRef]

56. Project H2020 AgriLink. Available online: https:/ / www.agrilink2020.eu/ (accessed on 31 January 2021).

57. Bardin, L. Análise de Conteúdo; Edições 70: Lisbon, Portugal, 2010. 
58. Baptista, A.; Cristóvão, A.; Rodrigo, I.; Tibério, M.L. Parcerias, acção coletiva e desenvolvimento de sistemas alimentares localizados: O projecto Prove em Portugal. Perspect. Rural. Nueva Época 2014, 23, 11-31.

59. The Measurement of Scientific and Technological Activities. 2009. Available online: https://www.oecd-ilibrary.org/science-andtechnology/oslo-manual_9789264013100-en (accessed on 1 December 2021).

60. OECD and Eurostat. Oslo Manual: Guidelines for Collecting and Interpreting Innovation Data; OECD: Paris, France, $2005 ;$ pp. 1-162. [CrossRef]

61. Simbiose. Available online: https://www.simbiose.com.pt/fat-portfolio/prove-o-projeto-que-permite-provar-localmente/ (accessed on 2 August 2021).

62. Wolfe, D.A.; Gertler, M.S. Innovation and Social Learning: An Introduction. In Innovation and Social Learning: Institutional Adaptation in an Era of Technological Change, 2nd ed.; Gertler, M.S., Wolfe, D.A., Eds.; Palgrave Macmillan: Basingstoke, UK, 2002; pp. 1-24.

63. Hultine, S.; Cooperband, L.; Curry, M.; Gasteyer, S. Linking Small Farms to Rural Communities with Local Food: A Case Study of the Local Food Project in Fairbury, Illinois. Community Dev. 2007, 38, 61-76. [CrossRef]

64. Tudisca, S.; Di Trapani, A.M.; Sgroi, F.; Testa, R. Socio-economic assessment of direct sales in Sicilian farms. Ital. J. Food. Sci. 2015, 27, 1-7. 